\title{
Government Expenditure and Economic Growth in South Africa: A Vector Error Correction Modelling and Granger Causality Test
}

\author{
Kagiso Molefe, Ireen Choga \\ School of Economic Sciences, North West University, South Africa \\ Edwardmolefe22@gmail.com, Ireen.Choga@nwu.ac.za
}

\begin{abstract}
Previous studies generally find mixed empirical evidence on the relationship between government spending and economic growth. This study re-examine the relationship between government expenditure and economic growth in South Africa for the period of 1990 to 2015 using the Vector Error Correction Model and Granger Causality techniques. The time series data included in the model were gross domestic Product (GDP), government expenditure, national savings, government debt and consumer price index or inflation. Results obtained from the analysis showed a negative long-run relationship between government expenditure and economic growth in South Africa. Furthermore, the estimate of the speed of adjustment coefficient found in this study has revealed that 49 per cent of the variation in GDP from its equilibrium level is corrected within of a year. Furthermore, the study discovered that the causality relationship run from economic growth to government expenditure. This implied that the Wagner's law is applicable to South Africa since government expenditure is an effect rather than a cause of economic growth. The results presented in this study are similar to those in the literature and are also sustained by preceding studies.

Keywords: Government Expenditure, Economic Growth, National Savings, VECM, South Africa
\end{abstract}

\section{Introduction}

Expenditure by government is still regarded as one of the major elements of economic growth in both advanced and emerging countries. Its significance towards economic growth continues to be a leading discussion between economists and policy makers not only in South Africa but all over the globe. Most countries still rely on spending by the government as their source of social security and expanded physical infrastructure. According to Wagner (1877), government expenditure will remain a source of economic growth and a tool to improve the welfare of most societies in emerging economies. He further emphasized that sustained government expenditure will result in jobs creation, improved physical infrastructure, increased educational investment as well as sustained economic growth. However, empirically the nature of the relationship between government expenditure and economic growth remains an extensive debate between researchers. According to Olulu, Erhieyovwe and Andrew (2014) cumulative government expenditure is detrimental to economic growth mainly due to that expenditure by government is associated with tax burden particularly on personal income. As a result, a large part of labor force is discouraged from working extended hours or even job hunting. According to the authors, this will have a direct effect on household consumption and savings which are regarded as the most essential components of growth. Opposing that, Brender and Drazen (2008) affirmed that government expenditure can yield good economic results if it is utilized for productive purposes such as investing in physical infrastructure as well as building human capital. According to Brender and Drazen, most economies fail predominantly due to that government expenditure is used for political significances. For instance, during the elections period, politician are confident to allocate a deficit budget in order to cater for voters through reducing tax base without reducing the spending. In South Africa, government expenditure was reduced from 27.6 per cent to 26.4 per cent of GDP following the inauguration of the democratic governance in 1994. This was a good indication that the government in power was taking the correct path in addressing the errors of the past regime. South African government continued being fiscal enthusiast and dedicated to cautious fiscal reforms up until 2009 where it recorded the highest of 27.8 per cent (see figure 1).The increase in government expenditure was conveyed by increase in social and economic programs to alleviate unemployment, poverty and to improve the quality of education and health care access to support underprivileged societies. Furthermore, the government was addressing economic challenges which were bought by the 2008/2009 global economic meltdown. 


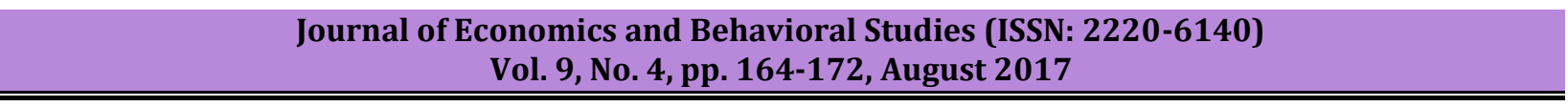

Figure 1: Government expenditure in South Africa

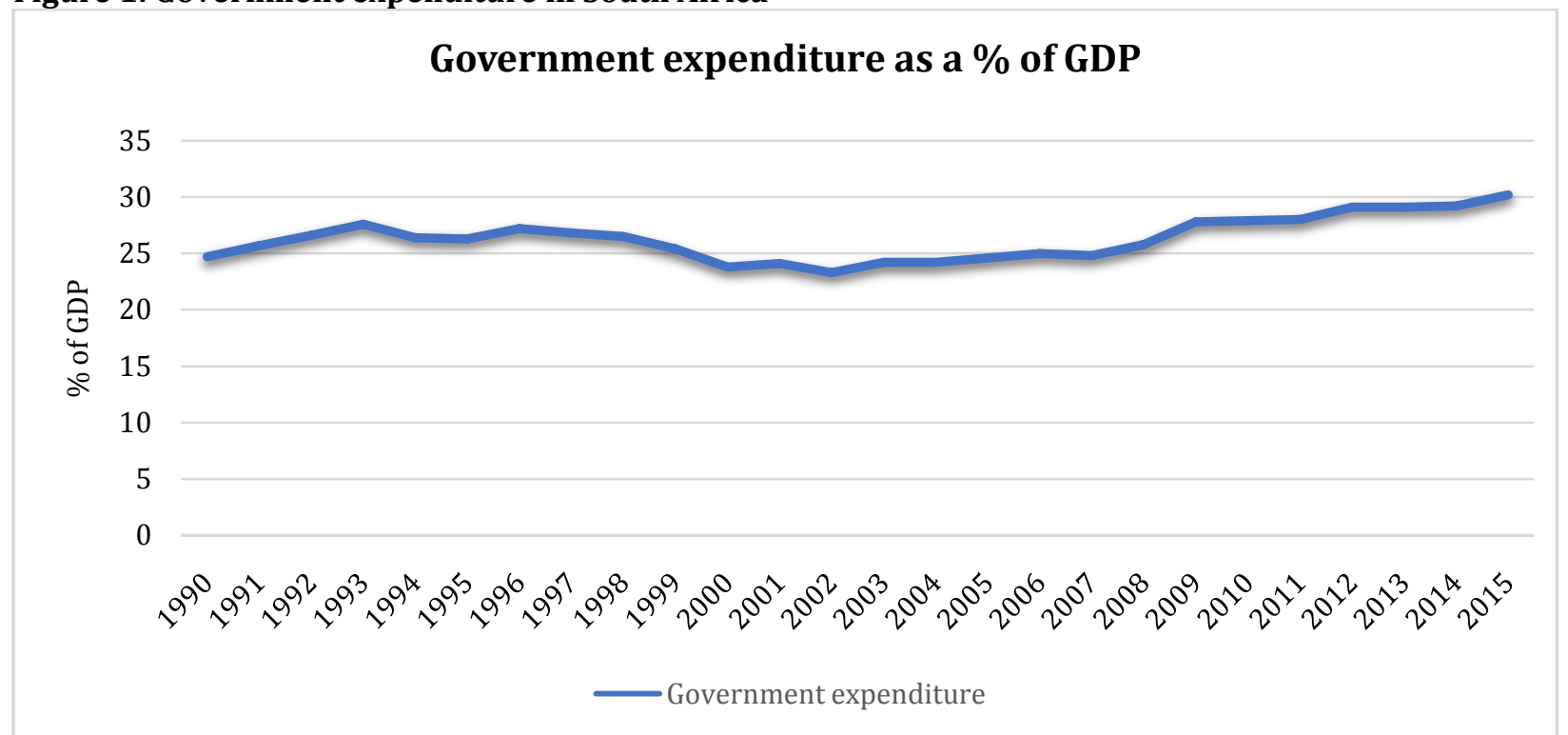

Source: author's own computation using data from World Bank

However, despite the increasing government expenditure in South Africa, the economy is still volatile with challenges such as high unemployment, poor infrastructure, above target inflation as well as partial access to education and health facilities. This challenges facing South Africa will definitely affect the magnitude of government's contribution towards the National Development Plan 2030. Therefore, the rationale of this study is to examine the effects of government expenditure on economic growth in South Africa. This undertaking is aimed at adding to the body of literature regarding the measurement and behaviour of government expenditure and economic growth. Moreover, the results obtained from the analysis will assist policymakers in finding an appropriate ways to stimulating economic growth in South Africa.The remaining part of this study are organized as follows: section 2 outlines both theoretical and empirical literature review, section 3 is the methodology employed, section 4 present the results followed by section 5 which is the conclusion and policy recommendation.

\section{Literature Review}

The theoretical literature regarding the relationship between government expenditure and economic growth is grounded on two well-known school of thoughts namely, the demand-side and the supply-side theory. According to the demand-side economic theory, there exist a positive relationship between government expenditure and economic growth. The theory supports vigorous government intervention in the economy to encourage the demand for goods and services and ensure economic growth and steadiness. However, the supply-side theory had a contradictory view regarding government intervention in the economy. According to the theory, government expenditure consists of bureaucratic waste and considered as a misrepresentation to economic growth. Wagner's law was one the most cited demand-side theory which is considered in this study. According to Wagner (1877), government expenditure is an endogenous variable that can used to drive the economy to the desired level. Therefore, government expenditure is an effect of economic growth rather than a cause. Wagner's argument was that as per capita income of a country increases, the significance of government expenditure grows relatively. This implies that the demand for goods and services supplied by government will increase due to technological requirements of industrialization and urbanisation that goes together with the income growth. According to the author, government expenditure will remain significant to promoting economic growth base on three principles. Firstly, development and transformation should result in public goods being replaced by private goods. Secondly, the growth in income elastic spending should be facilitated by the growth in real income. Lastly, government should take over the monopolies authorities and changes in technology. 
To assist in enhancing the theoretical understanding of the relationship between government expenditure and economic growth, the study included other school of thoughts. One of the other theories which laid a concrete foundation regarding the relationship between government expenditure and economic growth was the Keynes. Keynes (1936) treated government expenditure as an exogenous variable that can be utilised to enhance economic growth. According to Keynes, the economy without government intervention will fail as it was evident during the 1939 US Great Depression. Therefore, government expenditure causes economic growth and the casual relationship should run from government expenditure to economic growth not the other way round. However, according to other theories such as the endogenous growth model, the influence of government expenditure on economic growth depends largely on the size of the intervention. According to Pieroni (2007), the endogenous growth model affirmed that different kind of government expenditures have heterogeneous effects on economic growth, for instance, research and development, education and physical infrastructure are often categorised as public goods that have effects on economic growth. Contrary to this view, Barro $(1990,1991)$ articulated that government expenditure is associated with higher tax burden both on households and firms and as a result it distorts economic incentives (incentive to save and invest, incentive for modernization and enterprises) and delay economic development. During the commencement of the neo-classical growth models through the works of Solow (1956) it was argued that government expenditure does not have any effect on the growth of national output. However, it has been argued that government intervention assist in improving failure that might arise from the inefficiencies of the market.

The debate regarding the relationship between government expenditure and economic growth has led to division between policymakers and scholars as to whether government expenditure promotes or hinders growth. As a result, extensive range of empirical studies by different researchers and various results were obtained. Some researchers found that government expenditure promotes economic growth by providing valued public goods such as education and infrastructure whilst others argued that government expenditure weakens economic growth by transferring surplus resources from productive sector of the economy to government which utilise them less efficiently. Landau (1983) conducted a study in 104 advanced and emerging countries using the cross-country methodology, the author discovered that government expenditure delays economic growth. The result obtained confirmed the statement made by Barro (1990, 1991) that government expenditure has a negative impact on economic growth. In support, Komain and Brahmasrene (2007) employed the Granger causality test to examine the relationship between government expenditure and economic growth in Thailand. The authors found that government expenditure and economic growth are not related. The results also suggested a unidirectional relationship as causality runs from government expenditure to growth. Mo (2007) discovered contradictory results subsequent to conducting a study in 138 countries. According to Mo (2007), government expenditure affects economic growth positively through three channel namely, total factor productivity, gross fixed capital formation (investment) and aggregate demand. The results by the author confirmed the existence of the Keynesian theory in all 138 countries. Kesavarajah (2012) discovered that government expenditure is short-termed related to economic growth instead of long-termed subsequent to conducting a study in Sri Lanka. Furthermore, the author discovered that the Wagner's hypothesis holds in Sri-Lankan economy. Verna and Arora (2010) and Mulamba (2009) also discover that the Wagner's law is applicable in most countries than the Keynesian theory. However the Keynesian theories significant only to countries at the earliest stage of development.

\section{Data and Methodology}

This paper employs annual time series data spanning the period 1990 to 2015 derived from secondary sources. Five variables (gross domestic product, government expenditure, national savings, government debt and consumer price index) are employed. Furthermore, the paper adopt the Vector Error Correction Model (VECM) which requires that data should be tested for order of integration, variables should be tested for cointegration and the estimation of the long-run relationship as well as the speed of adjustment in which the dependent variable is corrected within a period of a year. To ensure the goodness of the model estimated, the paper will conduct the diagnostic tests (langrage multiplier test, Jarque-Bera and white test for heteroskedasticity). To assess how the dependent variable responds to shocks coming from selected independent variables, the paper will employ the variance decomposition and the general impulse response analysis. 
Empirical model specification: The model adopted in this paper to test for the relationship between government expenditure and economic growth was used by Chipaumire, Ngirande, Method and Ruswa (2014). The model can be expressed in linear form as follows:

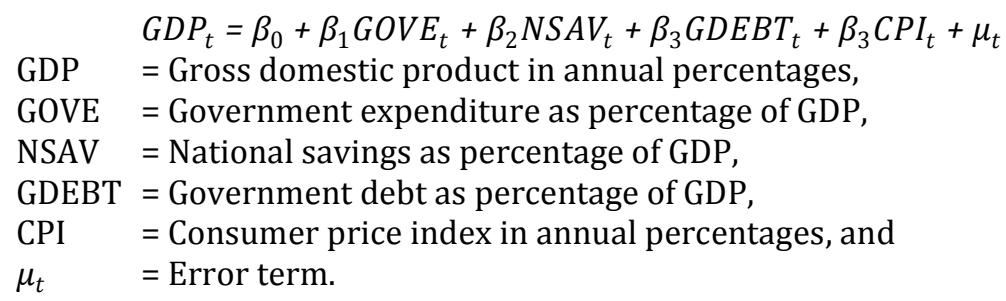

Data analysis: As already indicated, the VECM methodology requires the paper to test the data employed for stationarity or order of integration. The data is tested for stationarity or order of integration to avoid producing spurious results. The paper employed the Augmented Dickey-Fuller (ADF) and Phillip Perron (PP) techniques and the results are presented in Table 1 and 2.

Table 1: Augmented Dickey-Fuller test results

\begin{tabular}{llclll}
\hline Variable(s) & Model & ADF tests & Lag & $\begin{array}{l}\mathbf{5 \%} \text { critical } \\
\text { Value }\end{array}$ & $\begin{array}{l}\text { Order of } \\
\text { integration }\end{array}$ \\
\hline RGDP & Trend \& intercept & $-5.402^{* * *}$ & 0 & -3.612 & $\mathrm{I}(1)$ \\
GOVE & Trend \& intercept & $-5.026^{* * *}$ & 0 & -3.612 & $\mathrm{I}(1)$ \\
NSAV & Trend \& intercept & $-4.302^{* * *}$ & 0 & -3.645 & $\mathrm{I}(1)$ \\
GDEBT & Trend \& intercept & $-5.026^{* * *}$ & 0 & -3.612 & $\mathrm{I}(1)$ \\
INF & Trend \& intercept & $-5.307^{* * *}$ & 3 & -3.645 & $\mathrm{I}(1)$ \\
\hline$* /\left[\left[^{* *}\right] /\left[^{* * *}\right)\right.$ denotes significance at 10\%, /[5\%]/(1\%), level of significance respectively
\end{tabular}

Table 3: Phillip-Perron test results

\begin{tabular}{llllll}
\hline Variable(s) & Model & PP tests & Bandwidth & $\begin{array}{l}\mathbf{5 \%} \text { critical } \\
\text { value }\end{array}$ & $\begin{array}{l}\text { Order of } \\
\text { integration }\end{array}$ \\
\hline RGDP & Trend \& intercept & $-9.232^{* * *}$ & 14 & -3.612 & $\mathrm{I}(1)$ \\
GOVE & Trend \& intercept & $-7.035^{* * *}$ & 14 & -3.612 & $\mathrm{I}(1)$ \\
NSAV & Trend \& intercept & $-4.536^{* * *}$ & 0 & -3.612 & $\mathrm{I}(1)$ \\
GDEBT & Trend \& intercept & $-5.026^{* * *}$ & 0 & -3.612 & $\mathrm{I}(1)$ \\
INF & Trend \& intercept & $-6.006^{* * *}$ & 11 & -3.612 & $\mathrm{I}(1)$ \\
\hline$* /\left[{ }^{* *}\right] /\left(^{* * *}\right)$ denotes significance at $10 \%, /[5 \%] /(1 \%)$, level of significance respectively
\end{tabular}

It is evident from Tables 1 and 2 that the variables are all stationary at $1 \%, 5 \%$ and $10 \%$ level of significance. Therefore the paper rejects the null hypothesis of unit root in each case of the series and concludes that variables are integrated of the same order I (1) at first difference.

\section{Results}

Table 3: selection of lag order criteria

\begin{tabular}{llllllc}
\hline Lag & LogL & LR & FPE & AIC & SIC & HIQ \\
\hline 0 & -194.5181 & NA & 11.44287 & 16.62651 & 16.87194 & 16.69162 \\
1 & -150.5544 & $65.945^{*}$ & 2.486669 & 15.04620 & $16.51877^{*}$ & 15.43687 \\
2 & -118.5248 & 34.6984 & $1.895867^{*}$ & $14.46040^{*}$ & 17.16011 & $15.17663^{*}$ \\
* indicates lag order selection of criterion, LR: Sequential modified LR test Statistics (each \\
test at 5\% level). FPE: Final Prediction Error. AIC: Akaike Information Criterion. SC: \\
Schwarz Information Criterion. HQ: Hannan Quinn Information Criterion \\
\hline
\end{tabular}


Since the ADF and PP techniques confirmed that variables are integrated of same order I (1), the paper can then proceed to conduct a lag length selection test to establish the number of lag to employ in the analysis. According to Table 3, all criterions except for the Likelihood ratio (LR) and Schwarz Information Criterion (SIC) select a lag of 2. Based on the optimum lag length of 2, the Johansen technique is then performed using the Trace and Maximum Eigen-value. The results presented in Table 4 (Trace) suggest 1 cointegrating equation whilst Table 5(Maximum Eigen-value) suggest 0 cointegrating equation. As a result, the paper accepted the Trace results based on affirmation made by Lutkepohl, Saikkonen and Trenkler (2001) that the Trace statistic is more advantageous and accurate than the maximum eigenvalue statistics.

Table 4: Cointegration rank test (Trace test)

\begin{tabular}{|c|c|c|c|}
\hline $\begin{array}{l}\text { Hypothesized No. of } \\
\text { CE(s) }\end{array}$ & Trace Statistic & Critical & Prob.** \\
\hline None* & 72.27439 & 69.81889 & 0.0314 \\
\hline At most 1 & 42.30250 & 47.85613 & 0.1504 \\
\hline At most 2 & 24.43692 & 29.79707 & 0.1826 \\
\hline At most 3 & 9.782787 & 15.49471 & 0.2978 \\
\hline At most 4 & 1.330190 & 3.841466 & 0.2488 \\
\hline \multicolumn{4}{|c|}{$\begin{array}{l}\text { Trace test indicates } 1 \text { cointegrating equation }(s) \text { at the } 0.05 \text { level } \\
{ }^{*} \text { denotes rejection of the hypothesis at the } 0.05 \text { level }\end{array}$} \\
\hline
\end{tabular}

Table 5: Cointegration rank test (Maximum-Eigen test)

\begin{tabular}{|c|c|c|c|}
\hline $\begin{array}{l}\text { Hypothesized No. of } \\
\text { CE(s) }\end{array}$ & $\begin{array}{l}\text { Max-Eigen } \\
\text { Statistic }\end{array}$ & $\begin{array}{l}0.05 \\
\text { Value }\end{array}$ & Prob.** \\
\hline None* & 29.97189 & 33.87687 & 0.1364 \\
\hline At most 1 & 17.86557 & 27.58434 & 0.5063 \\
\hline At most 2 & 14.65414 & 21.13162 & 0.3139 \\
\hline At most 3 & 8.452597 & 14.26460 & 0.3346 \\
\hline At most 4 & 1.330190 & 3.841466 & 0.2488 \\
\hline \multicolumn{4}{|c|}{$\begin{array}{l}\text { Max-eigenvalue test indicates } 0 \text { cointegrating equation(s) at the } 0.05 \text { level } \\
\text { *denotes rejection of the hypothesis at the } 0.05 \text { level }\end{array}$} \\
\hline
\end{tabular}

The long-run estimation of the selected variables on economic growth in South Africa is tested using the VECM. Using the equation 1, the results are presented in Table 6 as follow:

Table 6: Long-run results: GDP

\begin{tabular}{llll}
\hline Variable(s) & Coefficient & $\begin{array}{l}\text { Standard } \\
\text { Errors }\end{array}$ & t-statistics \\
\hline GOVE $(-1)$ & -4.036 & 0.439 & -9.203 \\
NSAV $(-1)$ & -0.508 & 0.183 & -2.774 \\
GDEBT $(-1)$ & 1.342 & 0.123 & 10.954 \\
INF $(-1)$ & -0.213 & 0.051 & -4.171 \\
\hline
\end{tabular}

The long-run estimation results obtained in this study suggest that the long-run relationship between the variables understudy exist though it's negative. These results are consistent with studies conducted by Landau (1983) and Komain \& Brahmasrene (2007) also confirm the statement made by made by Barro (1990, 1991). Therefore, the study concludes that government expenditure is detrimental to economic growth. This might be due to the enormous size of government intervention among other reason as affirmed by Gallaway and Vedder (1998). Buiter (1975) also argued that large government intervention results in "crowding out" effect which was referred to Keynes as "diversion", where public spending crowd out private spending and investment. However, it is important to note that some of the relationships suggested by the long-run equation are not harmonious with theory, because the equation has wrong signs for some of the variables. Furthermore, the VECM results confirm the existence of error correction as shown in Table 7 below. The coefficient of the error term is -0.49 and statistically significant with $t$-value of -2.82 . This suggests that about $49 \%$ of the variation in GDP from its equilibrium level is corrected with a period of a year. 
Table 7: Error correction results: RGDP

\begin{tabular}{llll}
\hline Variable(s) & Coefficient & Standard Errors & t-statistics \\
\hline CointEq1 & -0.486 & 0.172 & -2.819 \\
D(GDP(-1)) & -0.157 & 0.248 & -0.634 \\
D(GDP(-2)) & -0.121 & 0.193 & -0.628 \\
D(GOVE(-1)) & -2.189 & 0.802 & -2.730 \\
D(GOVE(-2)) & -0.852 & 0.749 & -1.145 \\
D(NSAV(-1)) & -0.052 & 0.378 & -0.139 \\
D(NSAV(-2)) & 0.107 & 0.343 & 0.311 \\
D(GDEBT(-1)) & 0.134 & 0.402 & 0.334 \\
D(GDEBT(-2)) & -0.145 & 0.330 & -0.439 \\
D(INF (-1)) & -0.472 & 0.145 & -3.235 \\
D(INF(-2)) & -0.107 & 0.194 & -0.553 \\
\hline
\end{tabular}

The diagnostic checks were performed to confirm the goodness of fit of the model. The paper used technique such as langrage multiplier (LM) test for serial correlation, Jarque-Bera for normality test and the white test for heteroskedasticity. The results presented in Table 8 suggest that the model estimated is of good fit.

Table 8: Diagnostics tests results

\begin{tabular}{llll}
\hline Test for: & Test & P-value & conclusion \\
\hline Breuch-Godfrey Serial correlation & LM & 0.803 & Accept H0 \\
Heteroskedasticity & White & 0.452 & Accept H0 \\
Normality & Jarque-Bera & 0.528 & Accept H0 \\
\hline
\end{tabular}

The model was furthermore tested for stability by means of the Inverse Roots of AR Characteristic Polynomial technique. The results presented in figure 2 suggest that all the inverse roots are contained within the unit cycle and are less than 1 . This is a good indication that VAR fulfils the stability condition of the model estimated.

Figure 2: Stability results Inverse Roots of AR Characteristic Polynomial

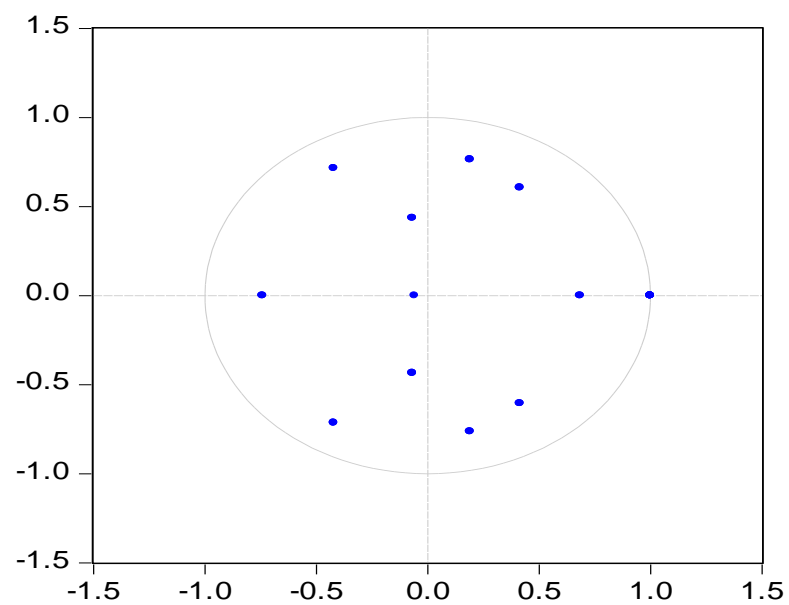

The results obtained in the Vector Error Correction Model specify the exogeneity or endogeneity of the variables in the system and the direction of Granger-causality within the sample period. However, they do not make available the dynamic properties of the system. The analysis of the dynamic interactions among the variables can be conducted through variance decompositions and general impulse response functions. Based on Table 9, the paper allow the variance decomposition of GDP over the period of 10 in order to establish the effects of the explanatory variables when they are allowed to affect the explained variable for a relatively longer time.In the first period, $100 \%$ of GDP variances can be explained by its own inventions. Its contribution kept of dropping with time until it reached $34.9 \%$ in the last year. This led to a conclusion that 
over 5 years ahead, GDP discrepancies can be described by its own shocks. Following GDP itself, the $2^{\text {nd }}$ up to the $8^{\text {th }}$ period reveals the significance of GOVE, NSAV, GDEBT and INF in explaining the variation of GDP. From the second year of the analysis it is evident that GOVE accounts for $0.1 \%$ of the variation in GDP whilst NSAV accounts for $1.4 \%$, GDEBT accounts for $10.1 \%$ and INF accounts $18.8 \%$.

Table 9: Variance Decomposition results: GDP

\begin{tabular}{lllllll}
\hline Period & S.E. & GDP & GOVE & NSAV & GDEBT & INF \\
\hline 1 & 1.181837 & 100.0000 & 0.000000 & 0.000000 & 0.000000 & 0.000000 \\
2 & 1.574715 & 69.50273 & 0.148330 & 1.444077 & 10.10970 & 18.79516 \\
3 & 2.085066 & 46.69727 & 25.78382 & 0.833004 & 15.08283 & 11.60308 \\
4 & 2.507698 & 32.88422 & 45.40148 & 0.682082 & 12.71231 & 8.319909 \\
5 & 2.697407 & 29.37973 & 49.46705 & 1.037020 & 12.55517 & 7.561029 \\
6 & 3.081391 & 34.20823 & 46.52235 & 0.842922 & 11.96964 & 6.456853 \\
7 & 3.378212 & 37.68731 & 42.67893 & 0.943798 & 12.87400 & 5.815963 \\
8 & 3.567021 & 36.49665 & 40.63000 & 1.712676 & 14.62980 & 6.530887 \\
9 & 3.784632 & 35.44572 & 41.68410 & 2.006162 & 15.06251 & 5.801498 \\
10 & 3.994492 & 34.96345 & 42.69957 & 2.107789 & 14.99754 & 5.231655 \\
\hline
\end{tabular}

Cholesky ordering: GDP, GOVE, NSAV, GDEBT, INF

The paper further applied the General Impulsive Response Function to trace the consequence of one-time shock to one of the innovations on the present and forthcoming values of the endogenous variables. The GIRF over the 10 years for the VECM estimation is shown in Appendix 1. Based on the analysis, the response of GDP to a shock in itself is positive over the period of the study. Moreover, Appendix 1 suggests that the response of GDP to shocks from GOVE is negative over the period of the study. This result permits the study to justify the decrease in the economic growth of South Africa due government expenditure among other reasons. The study further conducted the Granger causality test to analyse the cause and the effect relationship between government expenditure and economic growth. The causality results are presented in table 10.

Table 10: Pairwise Causality results

\begin{tabular}{lllll}
\hline Null Hypothesis: & Obs & F-stats & P-value & conclusion \\
\hline GOVEXP does not Granger cause GDP & 23 & 0.842 & 0.447 & No causality \\
GDP does not Granger cause GOVEXP & 23 & 4.769 & 0.017 & Causality \\
\hline
\end{tabular}

The results in table 10 clearly show that the causal relationship runs from economic growth to government expenditure. Therefore, the study concludes that the Wagner's law is applicable to South Africa since government expenditure is an effect rather than a cause of economic growth. Government expenditure in South Africa does not Granger because economic growth mainly due to that a large share of government expenditure goes towards non-productive sectors such as spending on defense, subsidies and political motivated recruitment in the public sector.

\section{Conclusion and Recommendations}

The main objective of this paper was to examine the nature of the relationship between government expenditure and economic growth in South Africa using annual data covering the period 1990 to 2015. The paper ensured that this objective is achieved by applying time series techniques such as the stationarity test (ADF) and (PP), cointegration test (Johansen procedure), Vector Error Correction Model (VECM), diagnostic tests as well as the Granger causality test. The unit root test confirmed that the variables employed in the study are integrated at the same order of I (1). The Johansen cointegration test proved a long-run relationship between the variables whilst the VECM provided parameter estimates for both long-run and the error correction. In determining the effects of government expenditure on economic growth in South Africa, the result obtained revealed a long-run negative relationship between government expenditure and economic growth in South Africa. The error correction results further revealed that there is a convergence towards 
steadiness in the long-run with the adjustment of $49 \%$ per annum. The Variance Decomposition and General Impulsive Response Function were also employed to measure the sensitivity of GDP towards shocks coming from the selected variables. The Granger causality test showed that the causal relationship runs from economic growth to government expenditure and confirmed the legitimacy of Wagner's law in South Africa. The policy implication of this negative relationship between government expenditure and economic growth in South Africa is that an increase of government expenditure will lead to a decrease in economic growth. This call for government in South Africa to strengthen polices such as fiscal consolidation and cost containment measures without curtailing its priorities. Furthermore, the government of South Africa should ensure its significance through partnering with private sectors, laborers and other stakeholder to promote economic growth.

\section{References}

Barro, R. J. (1990). Government spending in a simple model of endogenous growth. Journal of Political Economy, 98(1), 103-125.

Barro, R. J. (1991). Economic growth in a cross-section of countries. The Quarterly Journal of Economics, 106(2), 104-443

Buiter, W. H. (1975). Crowding out and the effectiveness of fiscal policy. Econometric Research Program, Research memorandum, 191.

Brender, A. \& Drazen, A. (2008). How Do Budget Deficits and Economic Growth Affect Reelection Prospects? Evidence from a Large Panel of Countries. American Economic Review, 98(5), 2203-2220.

Chipaumire, G., Ngirande, H., Method, M. \& Ruswa, Y. (2014). The impact of government spending on economic growth: case South Africa. Mediterranean Journal of Social Sciences, 5(1), 109 - 118

Gallaway, L. \& Vedder, R. (1998). Government and unemployment: Reply to De Long. Critical Review, 12(3), 253-264.

Kesavarajah, M. (2012). Wagner's Law in Sri Lanka: An Econometric Analysis. International Scholarly Research Network, Article ID 573826, 9 pages.

Keynes, J. M. (1936). The General Theory of Interest, Employment and Money, London: Macmillan.

Komain, J. \& Brahmasrene, T. (2007). The Relationship between Government Expenditures and Economic Growth in Thailand. Journal of Economics and Economic Education Research, 8(1), 93-102

Landau, D. L. (1983). Government expenditure and economic growth: a cross-country Study. Southern Economic Journal, 49(1), 783-792

Lutkepohl, H., Saikkonen, P. \& Trenkler, C. (2001). Maximum eigenvalue versus trace tests for the cointegration rank of a VAR process, 4(2), 257-310.

Mulamba, K. C. (2009). Long-run Relationship between Government Expenditure and Economic Growth: Evidence from SADC Countries: (unpublished PhD Thesis, University of Johannesburg, 2009).

Mo, P. H. (2007). Government expenditure and economic growth: the supply and demand sides. Fiscal Studies, 28(4), 497-522

National Treasury. (2015). National Budget Review. [Online] available from http://www.treasury.gov.za/documents/nationalbudgetreview [25 February 2015]

Olulu, R. M., Erhieyovwe, E. \& Andrew, U. (2014). Government Expenditure and Economic growth: The Nigerian Experience. Mediterranean Journal of Social Science, 10(1), 89-94

Pieroni, L. (2009). Military expenditure and economic growth. Routledge, Defence and Peace Economics, 20(4), 327-339

Solow, R. (1956). A Contribution to the Theory of Economic Growth. Quarterly Journal of Economics, 70(1), 65-94.

Verna, S. \& Arora, R. (2010). Does the India Economy support Wagner's Law? An Econometric Analysis. Eurasian Journal of Business and Economics, 5(2), 77 - 91.

Wagner, A. (1877). Three Extracts on Public Finance, translated and reprinted in R.A. Musgrave and A.T. Peacock (Ed), Classics in the Theory of Public Finance, London: MacMillan. 


\section{Appendixes}

Appendix 1: The General Impulsive Response Function

Response of GDP to Cholesky One S.D. Innovations

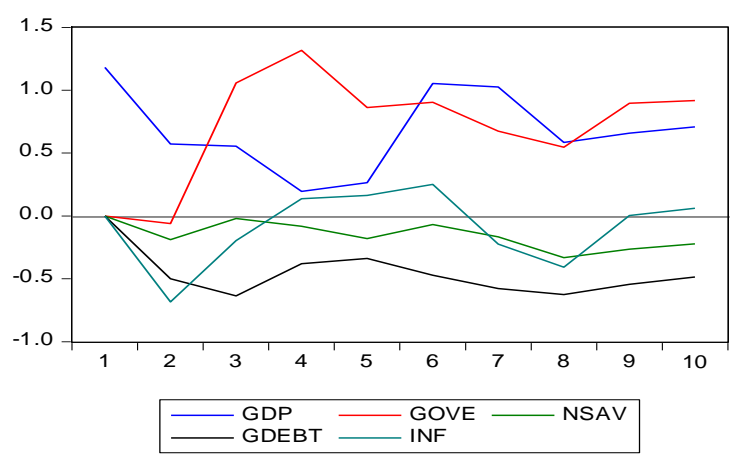

Response of NSAV to Cholesky One S.D. Innovations

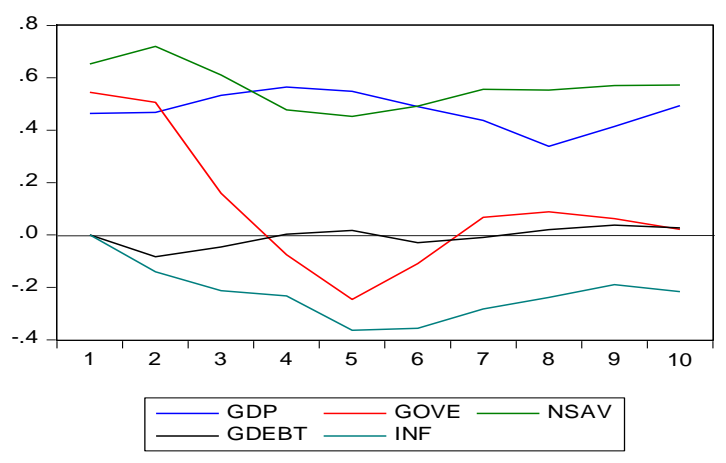

Response of INF to Cholesky One S.D. Innovations

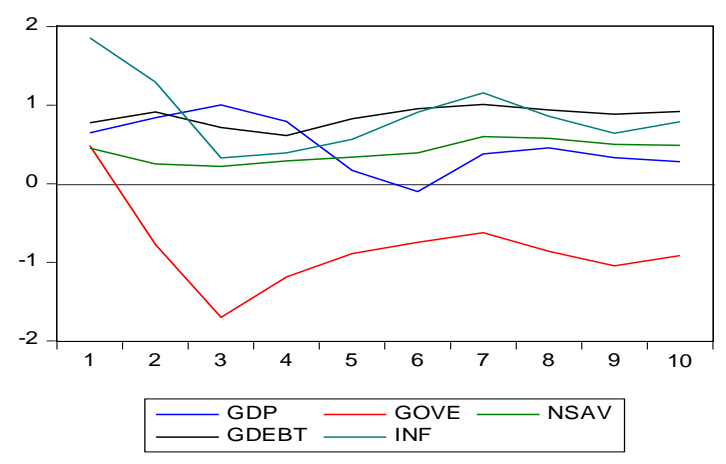

Response of GOVE to Cholesky One S.D. Innovations

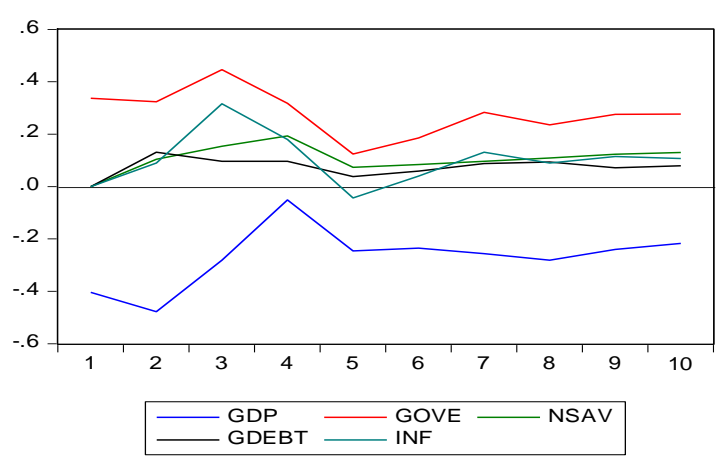

Response of GDEBT to Cholesky

One S.D. Innovations

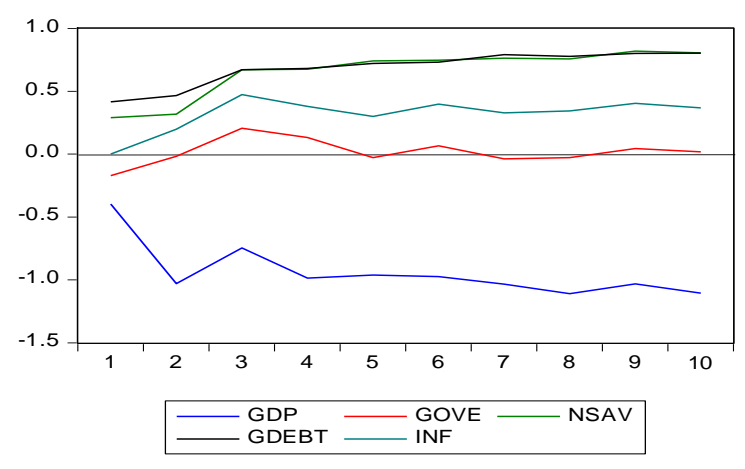

